\title{
PENGARUH LAMA FERMENTASI TERHADAP MUTU TEH DAUN GAMBIR (Uncaria Gambir Roxb.)
}

\author{
Andi Eviza'), Amaliyah Syariyah"), Deni Sorel ${ }^{1)}$ \\ 1) Prodi Budidaya Tanaman Perkebunan, Jurusan Budidaya Tanaman Perkebunan, Politeknik \\ Pertanian Negeri Payakumbuh
}

Korespondensi: evie.tadjuddin@gmail.com

\begin{abstract}
ABSTRAK
Tanaman gambir mengandung senyawa polifenol yang cukup tinggi, sama seperti senyawa yang terdapat dalam daun teh (Camelia sinensis). Banyak hasil penelitian menunjukkan bahwa senyawa polifenol bersifat sebagai antioksidan yang bermanfaat dalam mengobati penyakit ataupun menangkap radikal bebas yang terbentuk di dalam tubuh. Senyawa polifenol yang terdapat dalam daun gambir meliputi tanin, katekin, dan gambirin. Teh daun gambir dibuat melalui dua tahapan proses untuk memperoleh teh sesuai dengan formula yang diinginkan, yaitu pengolahan daun gambir menjadi daun gambir kering lalu dibuat menjadi teh daun gambir. Pengolahan lainnya, yaitu dengan melakukan proses fermentasi terhadap daun gambir. Perlakuan fermentasi pada pembuatan teh daun gambir masih bervariasi, belum dilakukan uji kandungan katekin, dan tannin yang merupakan kandungan utama dari gambir juga kandungan antioksidannya, kadar abu dan kadar airnya untuk mengetahui mutu dari teh herbal yang dihasilkan. Penelitian ini menggunakan Rancangan Acak Lengkap dengan 6 perlakuan lama proses fermentasi yaitu 18 jam, 24 jam, 30 jam, 36 jam, 42 jam dan 48 jam yang diulang sebanyak 4 kali. Hasil analisa laboratorium yang diperoleh rata-rata kandungan katekin pada tiap perlakuan 3,12\%, 2,17\%, 2,25\%, 1,82\%, 1,85\%, 1,69\%, kandungan taninnya 6,39\%, 5,51\%, 3,82\%, 2,43\%, 2,29\%, 1,78\%, aktivitas antioksidan 326,73ppm, 309,10ppm, 317,68ppm, 317,68ppm, 226,39ppm, 226,78ppm, kadar abu 2,62\%, $2,62 \%, 2,66 \%, 2,57 \%, 2,41 \%, 2,43 \%$, kadar air 8,42\%, 8,66\%, 8,58\%, 8,36\%, 8,33\% 8,40\%.
\end{abstract}

Kata kunci: fermentasi, gambir, tannin, katekin, antioksidan

\section{ABSTRACT}

Gambier plants contain polyphenol compounds that are quite high, just like the compounds found in tea leaves (Camelia sinensis). Many research showed that polyphenol compounds are antioxidants that are useful in treatingdiseases of capturing free radical that are formed in the body. Polyphenol compounds found in gambir leave include tannins, catechins, and gambirin. Gambier leaf tea I made through a two-stage process to obtain tea according to the desired formula, namely processing gambier leaves into dried gambier leaves and the making them into gambier leaf tea. Other processing, namely by carrying out the fermentation process of the gambier leaves. The fermentation treatments in the manufacture of gambier leaves tea is still varied. It has not been tested for the content of catechins and tannins which are the main content of gambier as well as its antioxidant content, ash content and water content to determine the quality of the herbal teas produced. This study used a Completely Randomized desaind with 6 duration treatment of the 
fermentation process, namely 18 hours, 24 hours, 30 hours, 36 hours, 42 hours, and 48 hours which was repeated 4 time. The results of laboratoryanalysis obtained that the average catechin content in each treatment was $3.12 \%, 2.17 \%, 2.25 \%, 1.82 \%, 1.85 \%, 1.69 \%$, the tannin content was $6.39 \%$, $5.51 \%, 3.82 \%, 2.43 \%, 2.29 \%, 1.78 \%$, antioxidant activity $326.73 \mathrm{ppm}, 309.10 \mathrm{ppm}, 317.68 \mathrm{ppm}$, $317.68 \mathrm{ppm}, 226.39 \mathrm{ppm}, 226.78 \mathrm{ppm}$, ash content $2.62 \%, 2.62 \%, 2.66 \%, 2.57 \%, 2.41 \%, 2.43 \%$, water content $8.42 \%, 8.66 \%, 8.58 \%, 8.36 \%, 8.33 \% 8.40 \%$.

Keyword: fermentation, gambier, tannin, catechin, antioxidant

\section{PENDAHULUAN}

Pada tahun 2016 konsumsi teh mencapai 5,5 juta ton sedangkan produksi teh Indonesia hanya sebesar 138.935 ton atau sebesar 2,5\% dari konsumsi dunia. Tanaman penghasil teh tersebut dinilai belum mampu untuk memenuhi kebutuhan quota ekspor keberbagai negara yang menjadi tujuan ekspor teh dari Indonesia, bahkan untuk memenuhi kebutuhan kebutuhan nasional. Pada akhir tahun 2018 produksi teh sedikit mengalami peningkatan menjadi 140.324 ton sedangkan kebutuhan adalah kurang lebih 155.000 ton teh dengan perincian 100.000 ton untuk kebutuhan dalam negeri, 49 ton akan diekspor dan sisanya 6.000 ton disiapkan sebagai stok nasional (Herdi, 2019). Kurangnya pemanfaatan bahan baku lain menjadi produk teh tersebut membuat perkembangan produk teh menjadi terhambat. Salah satu jenis tanaman yang mempunyai potensi yang cukup baik dan memiliki khasiat yang tidak kalah dari teh untuk diolah menjadi teh herbal adalah daun gambir.

Winarsih (2011) menyatakan bahwa teh herbal tidak berasal dari tanamanan daun teh yaitu Camellia sinenis. Teh herbal dapat dikonsumsi sebagai minuman sehat yang praktis tanpa mengganggu rutinitas sehari-hari dan tetap menjaga kesehatan tubuh. Teh herbal yang dibuat diharapkan dapat meningkatkan cita rasa dari tiap bahan yang digunakan tanpa mengurangi khasiatnya. Manfaat dari daun gambir selain untuk diambil getah yang dikandungnya dapat juga diolah menjadi menjadi berbagai produk, salah satunya teh herbal. Daun gambir lebih aman dikonsumsi dibanding daun teh, sebab senyawa katekin yang ada pada daun gambir ini tidak mengandung kafein seperti halnya teh (Bakhtiar, 2014)

Tanaman gambir mengandung senyawa polifenol yang cukup tinggi, sama seperti senyawa yang terdapat dalam daun teh (Camelia sinensis). Banyak hasil penelitian menunjukkan bahwa senyawa polifenol bersifat sebagai antioksidan yang bermanfaat dalam mengobati penyakit ataupun menangkap radikal bebas yang terbentuk di dalam tubuh. Senyawa polifenol yang terdapat diekstrak gambir ini adalah katekin yang berperan sebagai senyawa antimikroba dan antioksidan 
(Aditya \& Ariyanti, 2016). Diet yang kaya antioksidan akan menurunkan risiko terkena penyakit jantung, kanker, dan proses degeneratif penuaan. Senyawa polifenol yang terdapat dalam daun gambir meliputi tanin, katekin, dan gambiriin (Hermani, 2014).

Teh yang selama ini dikonsumsi dari daun teh Camellia sinensis ternyata mengandung zat tanin yang tinggi dalam teh berpotensi sebagai penyebab anemia karena disinyalir mampu mengabsorbsi mineral sebagai bentuk zat besi. Seperti dikutip dari data (Kementerian Pertanian, 2020), daun gambir juga mengandung tanin, tetapi lebih sedikit dibandingkan dengan daun teh Camellia sinensis. Dengan pengolahan yang tepat, teh daun gambir menghasilkan teh yang tidak kalah rasa dan aromanya, juga lebih sehat.

Teh daun gambir dibuat melalui dua tahapan proses untuk memperoleh teh sesuai dengan formula yang diinginkan, yaitu pengolahan daun gambir menjadi daun gambir kering lalu dibuat menjadi teh daun gambir. Pengolahan lainnya, yaitu dengan melakukan proses fermentasi terhadap daun gambir. Hal ini dimaksudkan untuk mengurangi senyawa asam katekutanat atau kadar tanin yang tidak diinginkan.

Tanin adalah beberapa antioksidan berjenis polifenol (yang mencegah atau mentralisasi efek radikal bebas yang merusak) yang menyatu dan mudah teroksidasi menjadi asam tanat. Asam tanat berfungsi membekukan protein yang berefek negatif pada mukosa lambung. Mukosa lambung orang - orang yang secara teratur minum teh (baik itu teh hijau, teh cina, teh hitam) atau kopi yang mengandung banyak asam tanat, baisanya telah menipis karena atrofi. Perubahan atrofi yang kronis atau mag kronis dapat dengan mudah berkembang menjadi kanker lambung (Hermani, 2014).

Katekin adalah segolongan metabolit sekunder yang secara alami dihasilkan oleh tumbuhan dan termasuk dalam golongan flavonoid. Senyawa ini memiliki aktivitas antioksidan berkat karena gugus fenol yang dimilikinya. Katekin juga ditengarai bukan sekadar antioksidan namun juga super oksidan lantaran diyakini bisa memberikan pencegahan berbagai penyakit. Katekin disebut bisa mencegah penyakit jantung, kelebihan berat badan, dan bermanfaat dalam pembentukan kolagen. Pada daun teh segar, kadar katekin bisa mencapai 30 persen dari berat daun kering. Teh hijau dan teh putih memiliki kandungan katekin yang cukup tinggi, namun teh hitam mengandung lebih sedikit katekin karena banyak yang hilang dalam proses oksidasi (Yasmin, 2016). Selanjutnya dijelaskan juga bahwa katekin adalah senyawa dominan dari polifenol yang larut dalam air, tidak berwarna dan tidak memberikan rasa pahit, yang 
mempunyai segudang manfaat, yaitu sebagai anti virus, anti radang dan anti bakteri. Komponen yang terkandung dalam teh daun gambir ini bila dikonsumsi dapat berperan dalam tubuh untuk memperbaiki kerusakan yang kognitif dan juga menghambat proses penimbunan lemak.

Antioksidan merupakan senyawa kimia yang memiliki kemampuan untuk memberikan hidrogen radikal untuk memadamkan oksigen radikal, sehingga tercapai keseimbangan antioksidan-antioksidan, yang dapat mengatur fungsi sistem imun dalam menjaga integritas fungsi lipida membran, protein seluler, asam nukleat serta mengatur ekspresi gen, yang dapat mencegah timbulnya kanker. Antioksidan alami adalah antioksidan yang berasal dari hasil ekstraksi bahan alam pada tumbuhan. Senyawa antioksidan alami meliputi betakaroten, likopen, asam askorbat (vitamin C), tokoferol (vitamin E) dan zat lainnya (Charlinia, 2016).

Antioksidan dapat diperoleh dari makanan yang banyak mengandung vitamin $\mathrm{C}$, vitamin E dan beta karoten serta senyawa fenolik. Bahan pangan yang dapat menjadi sumber antioksidan alami, seperti rempah-rempah, coklat, biji-bijian, buah-buahan, sayur-sayuran seperti buah tomat, pepaya, jeruk dan sebagainya (Marjoni et al., 2015). Antioksidan dari tumbuhan bekerja menghalangi kerusakan oksidatif dengan membentuk kelat dengan senyawa logam katalitik, dan menangkap oksigen (Marjoni et al., 2015). Leliqia et al. (2014) menambahkan bahwa ekstrak produk gambir memiliki aktivitas antioksidan yang lebih besar dibandingkan dengan ekstrak produk teh dan sebanding dengan vitamin C.Sifat antioksidan merupakan parameter yang sangat penting dalam mengembangkan pangan fungsional (Permana et al., 2012).

Maulana (2015) menyatakan bahwa kadar abu merupakan campuran dari komponen anorganik atau mineral yang terdapat pada suatu bahan pangan. Bahan pangan terdiri dari $96 \%$ bahan anorganik dan air, sedangkan sisanya merupakan unsur-unsur mineral. Unsur itu juga dikenal sebagai zat organik atau kadar abu. Kadar abu tersebut dapat menunjukkan total mineral dalam suatu bahan pangan. Bahan-bahan organik dalam proses pembakaran akan terbakar tetapi komponen anorganiknya tidak, karena itulah disebut sebagai kadar abu.Kadar abu dalam bahan pangan sangat mempengaruhi sifat dari bahan pangan,dan merupakan ukuran dari jumlah total mineral yang terdapat dalam bahan pangan tersebut.

Air merupakan salah satu karakteristik yang sangat penting bagi bahan pangan, karena kandungan air pada bahan pangan dapat mempengaruhi penampakan dan cita rasa makanan. Kadar air merupakan salah satu faktor yang sangat berpengaruh terhadap daya tahan bahan pangan, semakin tinggi kadarair bahan pangan maka semakin cepat terjadi kerusakan, dan 
sebaliknya semakin rendah kadar air bahan pangan maka bahan pangan tersebut semakin tahan lama (Andarwulan et al., 2011).

\section{BAHAN DAN METODE}

Penelitian telah dilakukan pada bulan Juli - November 2020, di laboratorium Kimia Politeknik Pertanian Negeri Payakumbuh. Bahan yang digunakan dalam pelaksanaan penelitian ini adalah daun gambir, air, bahan kimia untuk analisis kandunan katekin dan tanin teh herbal gambir yang dihasilkan. Sedangkan alat yang digunakan adalah mesin pencacah daun, kotak fermentasi, oven dan perangkat peralatan yang dipergunakan untuk analisis kandungan katekin dan tanin the yang dihasilkan.

Penelitian ini menggunakan Rancangan Acak Lengkap dengan 6 perlakuan lama proses fermentasi yaitu 18 jam, 24 jam, 30 jam, 36 jam, 42 jam dan 48 jam yang diulang sebanyak 4 kali. Daun gambir yang telah dicacah difermentasi berdasarkan perlakuan yang diujicobakan, yaitu 18 jam, 24 jam, 30 jam, 36 jam, 42 jam dan 48 jam. Selanjutnya dilakukan uji kimia berupa analisis kandungan katekin, tannin dengan pengujian menggunakan metode spektrofotometri dan diukur pada panjang gelombang $760 \mathrm{~nm}$ (Ryanata, 2014), aktivitas antioksidan (Metode DPPH), kadar abu dan kadar air dari teh daun gambir yang dihasilkan.

\section{HASIL DAN PEMBAHASAN}

Hasil analisa terhadap teh daun gambir, diperoleh kandungan tanin dan katekinnya seperti disajikan pada Tabel 1. 
Tabel 1. Perbandingan rata-rata kandungan tannin dan katekin teh daungambir berdasarkan perlakuan lama fermentasi

\begin{tabular}{|c|c|c|c|c|c|c|c|}
\hline \multirow[t]{2}{*}{ Analisis } & \multirow[t]{2}{*}{ Satuan } & \multicolumn{6}{|c|}{ Teh daun gambir dengan berbagai perlakuan lama fermentasi (jam) } \\
\hline & & A & $\mathrm{B}$ & $\mathrm{C}$ & $\mathrm{D}$ & $\mathrm{E}$ & $\mathrm{F}$ \\
\hline Tanin & $\%$ & $6,39 \mathrm{a}$ & $5,51 \mathrm{~b}$ & $3,28 \mathrm{c}$ & $2,43 \mathrm{~d}$ & $2,29 \mathrm{e}$ & $1,78 \mathrm{f}$ \\
\hline Katekin & $\%$ & $2,17 \mathrm{c}$ & $3,21 \mathrm{a}$ & $2,25 \mathrm{~b}$ & $1,82 \mathrm{~d}$ & $1,85 \mathrm{~d}$ & $1,69 \mathrm{e}$ \\
\hline $\begin{array}{l}\text { Aktivitas ntioksidan } \\
\text { (IC 50) }\end{array}$ & ppm & $326,73 a$ & $309,10 \mathrm{c}$ & $317,68 b$ & $317,68 b$ & $228,39 d$ & $226,78 \mathrm{e}$ \\
\hline \multicolumn{8}{|l|}{ Kadar Abu } \\
\hline Kadar Air & $\%$ & 2,62 & 2,62 & 2,66 & 2,57 & 2,41 & 2,43 \\
\hline & $\%$ & 8,42 & 8,66 & 8,58 & 8,36 & 8,33 & 8,40 \\
\hline
\end{tabular}

Keterangan : $A$ : 18 jam, B : 24 jam, $C: 30$ jam, D : 36 jam, E : 42 jam, F : 48 jam Angka pada lajur yang sama yang diikuti oleh huruf kecil berbeda menunjukkan perbedaan yang nyata pada taraf $5 \%$ menurut uji DNMRT

Dari data pada Tabel 1dapat dijelaskan bahwa persentase kandungan tanin dari teh daun gambir yang dihasilkan memperlihatkan persentase yang semakin menurun dengan semakin lamanya proses fermentasi berlangsung dan berbeda nyata dari setiap perlakuan. Tujuan dilakukannya fermentasi pada pembuatan teh daun gambir ini dimaksudkan untuk menurunkan kadar tanin yang terkandung dalam daun gambir yang mengakibatkan rasa kelat yang kental. Kisaran persentase tanin dalam teh daun gambir yang dihasilkan adalah 1,78 - 6,39\% yang masih berada dalam bahkan dibawah persentase standar kandungan tanin untuk teh Cameilia sinensis yang masih dibolehkan, yaitu 5 - $15 \%$. Menurunnya kadar tanin disebabkan terjadinya proses oksidasi terhadap tanin menjadi senyawa theaflavin, thearubigin dan thenaftoquinon akibat dari proses fermentasi. Semakin lama fermentasi dilakukan maka semakin banyak tanin yang mengalami perubahan akibat oksidasi dan menyebabkan kadar tanin dalam daun menjadi berkurang. Hal ini sesuai dengan pernyataan (Riski et al., 2016) yang menyatakan bahwa akibat dari fermentasi, banyak zat-zat yang berguna seperti katekin, tanin, vitamin berubah atau hilang pada saat proses produksi teh hitam, sehingga perlakuan fermentasi tidak boleh terlalu lama. Selanjutnya (Siringoringo, 2012) dalam penelitiannya mengenai studi pembuatan teh daun kopi dengan variasi lama fermentasi, menjelaskan bahwa terjadinya proses fermentasi oksidatif yang semakin lama dapat menyebabkan terjadinya penurunan kadar tanin. Hal ini disebabkan karena 
proses fermentasi oksidatif menyebabkan tanin berubah menjadi senyawa polifenol flavonoid. Tanin bukan merupakan zat gizi, namun dalam jumlah kecil dapat bermanfaat bagi kesehatan. Pada beberapa olahan teh maupun teh herbal, kandungan tanin dipertahankan dalam jumlah tertentu dengan tujuan untuk memberikan manfaat fungsional.

Kandungan katekin pada teh daun gambir yang dihasilkan cenderung semakin menurun dengan semakin lamanya proses fermentasi berlangsung. Keadaan ini disebabkan karena semakin lama terjadi proses fermentasi akan mengkibatkan beberapa kandungan bahan dalam daun akan hilang. Dari data pada Tabel 1 terlihat bahwa makin lama proses fermentasi berlangsung, kandungan katekin dari teh gambir yang dihasilkan juga semakin kecil. Hal ini sesuai dengan pernyataan (Riski et al., 2016) yang menyatakan bahwa akibat dari fermentasi, banyak zat-zat yang berguna seperti katekin, tanin, vitamin berubah atau hilang pada saat proses produksi teh hitam, sehingga perlakuan fermentasi tidak boleh terlalu lama.

Katekin berperan penting di dalam menentukan aroma dan rasa teh. Katekin merupakan senyawa tidak berwarna dan larut dalam air serta membawa sifat pahit dan sepat pada seduhan teh. Senyawa ini paling penting dalam daun teh karena dapat menentukan kualitas teh dalam pengolahanya. Dalam pengolahan, secara langsung atau tidak langsung, perubahan katekin selalu dihubungkan dengan semua sifat teh jadi, yaitu rasa, warna, dan aroma. Katekin yang mendominasi $20 \%$ berat kering teh merupakan substansi utama yang menyebabkan teh memenuhi persyaratan sebagai minuman fungsional (Anjarsari, 2016).

Aktivitas antioksidan teh daun gambir yang dihasilkan dari berbagai perlakuan lamanya fermentasi memperlihatkan bahwa semakin lama proses fermentasi berlangsung maka semakin tinggi aktivitas antioksidannya. Dari hasil analisis, diperoleh kisaran nilai aktivitas antiokidan 326,73 - 226,78 ppm yang dapat dikatakan bahwa dari semua perlakuan fermentasi selama pembuatan teh gambir, masih menghasilkan teh dengan potensi aktivitas antioksidan yang cukup tinggi. Meningkatnya aktivitas antioksidan dapat disebabkan adanya fenolik bebas yang dihasilkan selama proses fermentasi, sehingga semakin lama proses fermentasi berlangsung maka akan semakin banyak fenolik bebas yang dihasilkan, sehingga semakin tinggi aktivitas antioksidannya (Suhardini \& Zubaidah, 2016). Selanjutnya dijelaskan bahwa sifat antioksidan merupakan parameter yang sangat penting dalam mengembangkan pangan fungsional (Permana et al., 2012). Senyawa ini memiliki berat molekul kecil, tetapi mampu menginaktivasi berkembangnya reaksi oksidasi dengan mengikat radikal bebas dan molekul yang sangat reaktif. 


\section{KESIMPULAN}

Dari penelitian yang telah dilaksanakan pada pembuatan teh daun gambir yang dihasilkan berdasarkan lamanya waktu fermentasi dapat dsimpulkan bahwa makin lama waktu fermentasi yang dilakukan terhadap teh daun gambir maka aktivitas antioksidan mempunyai nilai (IC50) yang makin menurun, demikian pula halnya dengan kandungan tanin dan katekin. Jadi semakin lama waktu fermentasi dilakukan maka mutu kimia teh daun gambir semakin baik dan lebih aman untuk dikonsumsi.

\section{DAFTAR PUSTAKA}

Aditya, M., \& Ariyanti, P. R. (2016). Manfaat gambir (Uncaria gambir Roxb) sebagai Antioksidan. Jurnal Majority, 5(3), 129-133.

Andarwulan, N., Kusnandar, F., \& Herawati, D. (2011). Analisis Pangan. Dian Rakyat. Jakarta.

Anjarsari. (2016). Katekin Teh Indonesia : Prospek dan Manfaatnya. Jurnal Kultivasi, 15(2), 99106.

Bakhtiar, A. (2014, May 28). Teh dari Daun Gambir. Republika. http://www.republika.co.id

Charlinia, W. (2016). Pengaruh Penambahan Buah Mengkudu (Morinda citrifolia L.) Terhadap Aktivitas Antioksidan Dan Kadar Kafein Biji Kopi Robusta (Coffea canephora) [Universitas Bengkulu]. www.repository.unib.ac.id

Herdi, A. A. . (2019, March 18). Pengusaha Keluhkan Luas Kebun Teh dan Produksi yang Terus Turun. Detik Finance. www.finance.detik.com

Hermani. (2014). Teh Daun Gambir. Warta Penelitian Dan Pengembangan Pertanian, 10-11. https://www.litbang.pertanian.go.id/

Kementerian Pertanian. (2020). Tanin. Badan Penelitian dan Pengembangan. Kementerian Pertanian. Jakarta.

Leliqia, N. P. E., Susanti, N. M. P., \& Chanjaya, C. (2014). Pengaruh Lama Fermentasi Terhadap Aktivitas Antioksidan Minuman Kambucha Lokal Di Bali Dengan Substrat Produk Gambir. Jurnal Farmasi Udayana, 3(1). https://ojs.unud.ac.id/index.php/jfu/article/view/13122

Marjoni, Afrinaldi, \& Novita. (2015). Kandungan Total Fenol Dan Aktivitas Antioksidan Ekstrak Air Daun Kersen (Muntingia calabura L.). Jurnal Kedokteran Yarsi, 23(3), 187-196.

Maulana, A. (2015). Analisis Parameter Mutu Dan Kadar Flavonoid Pada Produk Teh Hitam 
Celup [Universitas Pasundan]. http://repository.unpas.ac.id/id/eprint/15717\%0AActions (login required)

Permana, A. W., Widayanti, S. M., Prabawati, S., \& Setyabudi, D. A. (2012). Sifat Antioksidan Bubuk Kulit Buah Manggis (Garcinia mangostana L.) Instan dan Aplikasinya untuk Minuman Fungsional Berkarbonasi. Jurnal Pascapanen, 9(2), 88-95.

Riski, T., Faizah, H., \& Raswen, E. (2016). Lama Fermentasi Terhadap Mutu Teh Daun Sirsak (Annona muricata L.). JOM Faperta UR, 3(2).

Ryanata, E. (2014). Penetuan Jenis Tanin dan Penetapan Kadar Tanin dari Kulit Buah Pisang Masak (Musa paradisica L) secara Spektrofotometri dan Permanganometri. Jurnal Ilmiah Mahasiswa Universitas Surabaya, 4(1).

Siringoringo, F. H. T. (2012). Studi Pembuatan Teh Daun Kopi [Universitas Sumatra Utara]. www.repsitory.usu.ac.id

Suhardini, N. P., \& Zubaidah, E. (2016). Studi Aktivitas Antioksidan Kombucha. Berbagai Jenis Daun. Jurnal Pangan Dan Agroindustri, 4(1), 221-229.

Winarsih. (2011). Antioksidan Alami dan Radikal Bebas. Potensi dan Aplikasinya dalam Kesehatan. Kanisius. Yogyakarta.

Yasmin, P. A. (2016). Tak Cuma Teh, Ekstrak Gambir Juga Punya Antioksidan Katekin Tinggi. DetikHealth. www.detikHealth.com 